\title{
SEASONAL CHANGES OF PROTEINS, STRUCTURAL CARBOHYDRATES, FATS AND MINERALS IN HERBAGE DRY MATTER OF RED CLOVER (Trifolium pratense $\mathrm{L}$.)
}

\author{
S. Vasiljević ${ }^{1}$, B. Ćupina ${ }^{2}$, Đ. Krstic ${ }^{2}$, I. Pataki ${ }^{1}$, S. Katanski ${ }^{1}$, B. \\ Milošević $^{1}$
}

\author{
${ }^{1}$ Institute of Field and Vegetable Crops, Novi Sad, Republic of Serbia \\ ${ }^{2}$ University of Novi Sad, Faculty of Agriculture, Republic of Serbia \\ Corresponding author: sanja.vasiljevic@ifvens.ns.ac.rs \\ Original scientific paper
}

Abstract: Red clover (Trifolium pratense L.) is the second most important perennial forage legume, after alfalfa. It is a significant source of proteins, which are essential in the diet of domestic animals, especially ruminants. The objective of this study was to determine the most important characteristics of dry matter quality (crude proteins, structural carbohydrates, fats and minerals) in three varieties of red clover (K-17, Kolubara and Una). The characteristics were monitored, per individual cuts, during one production cycle of red clover, i.e., in the period 20042006. Highest contents of crude protein in all three test years were obtained in the second cut. Significantly increased contents of crude proteins $(18.32 \%)$ and potassium (K-2.53\%) were found in the red clover cultivar Una developed in Novi Sad. Significantly increased values of both cellulose fiber fractions (NDF, ADF) were registered in the second year of growing. The highest content of minerals was determined at the beginning of the growing season in the first and second year ( $8.68 \%$ and $8.52 \%$, respectively). Here it should be mentioned that the contents of basic biogenous elements, phosphorus and potassium, were within the expected optimum range.

Key words: red clover (Trifolium pratense L), forage quality, cultivar, cut, seasonal changes

\section{Introduction}

Red clover (Trifolium pratense L.) is the second most important perennial forage legume, after alfalfa. As fodder, it is used both fresh and processed (hay, haylage, flour, silage). Red clover exceeds corn and oat grains in the content of essential amino acids (cystine, tryptophan, leucine). Red clover foliage is 
particularly rich in proteins. Protein content reaches about $25 \%$ at the stage of budding, which makes red clover leaves an important ingredient of quality forage (Vasiljevic et al., 2009). The high content of soluble carbohydrates makes it a good energy feed, better than alfalfa or Italian ryegrass. Red clover contains large amounts of provitamin $\mathrm{A}$ and vitamins $\mathrm{C}, \mathrm{D}, \mathrm{E}, \mathrm{K}, \mathrm{B}_{1}, \mathrm{~B}_{2}$ and $\mathrm{B}_{3}$. It is also rich in minerals (Marković et al., 2007).

The quality of red clover forage depends primarily on the stage of development and environmental conditions. Taylor and Quesenberry (1996) claimed that the content of crude proteins and in vitro dry matter digestibility are the two most reliable quality characteristics. Their value decreases with age, as a result of a decreasing portion of leaves in relation to stems and the process of lignification, which are typical for all perennial legumes. The decline in digestibility after budding is associated with increased contents of lignin and structural polysaccharides.

Stage of development, i.e., plant age, affects considerably the chemical composition and forage quality of red clover (Ignjatović et al., 2001; Marković et al., 2007; Belanger, 2010). In early spring, young red clover plants have a high proportion of leaves, high contents of moisture, proteins and minerals and a low content of fibers. During growing season, under the effect of longer days and higher temperatures, the aging plants undergo morphological changes: leaf growth becomes slower, the stem increases in length and the proportion of dry matter increases. On the other hand, forage quality decreases drastically, especially digestibility and the contents of proteins and minerals. The optimum time for red clover cutting, in terms of both, forage quality and total yield, is the stage when 20$25 \%$ flowers are in bloom (Fairey, 1988; Wiersma et al., 1998). At that stage, dry matter digestibility ranges from 65 to $70 \%$.

Also, the stress caused by unfavorable environment as well as by seasonal changes may cause a significant decline in forage quality of red clover, as a consequence of altered leaf to stem proportion (in favor of the stem) and accelerated aging (Taylor and Qusenberry, 1996). However, the research on red clover conducted by Buxton et al. (1985) showed that the aging does not cause a drastic drop in quality as is the case with some other perennial legumes (such as alfalfa and yellow trefoil). This is due to a higher portion of leaves and lower contents of cell wall and lignin (Buxton and Hornstein, 1986).

The objective of this study was to determine, in the course of a three-year production cycle (2004-2006), the most important characteristics of dry matter quality (crude proteins, structural carbohydrates, fats and minerals) in three varieties (K-17, Kolubara and Una), which dominate the commercial red clover production in the Republic of Serbia. 


\section{Materials and Methods}

The red clover varietal trial was established in spring 2004 at the experiment field at Rimski Šančevi, on the chernozem soil. The trial was organized in a randomized block design with five replications. The experimental unit area was $5 \mathrm{~m}^{2}$, the row spacing was $20 \mathrm{~cm}$, and the seeding rate was $15 \mathrm{~kg} \mathrm{ha}^{-1}$. Two cuts were performed in the first year, the first one in the second half of July (21 July 2004), at the stage of full bloom, and the second in the first half of September (11 September 2004). Four cuts were performed in the second year of the trial: 13 May, 23 June, 1 August and 6 October 2005, all in the early blooming stage. Two cuts were performed in the third year, on 18 May and 27 June 2006. The most important quality characteristics of red clover herbage (crude proteins, structural carbohydrates, fats, minerals, macroelements $\mathrm{P}, \mathrm{Ca}, \mathrm{K}$ and $\mathrm{Na}$ ) were determined by conventional methods performed in the laboratory of Department for Animal Feed Analysis of Department for Animal Husbandry, Faculty of Agriculture in Novi Sad.

Results of the three-year trial were analyzed by the analysis of variance and tested by the LSD test.

Meteorological conditions. Novi Sad and its surroundings are located in a zone of the temperate continental climate. The long-term (1948-1993) average precipitation for the vegetation period is $338 \mathrm{~mm}$ and average temperature for the same period is $17.8^{\circ} \mathrm{C}$ (Table 1$)$.

Table 1. Rainfall and mean monthly temperatures per growing season (2004-2006) and longterm averages (1948- 1993)

\begin{tabular}{|c|c|c|c|c|c|c|c|c|}
\hline Month & \multicolumn{4}{|c|}{ Rainfall $(\mathrm{mm})$} & \multicolumn{4}{c|}{ Temperature $\left({ }^{\circ} \mathrm{C}\right)$} \\
\hline & 2004 & 2005 & 2006 & $1948-1993$ & 2004 & 2005 & 2006 & $1948-1993$ \\
\hline IV & 112 & 31 & 65 & 48 & 12,5 & 12,0 & 13,0 & 11,4 \\
\hline V & 89 & 37 & 72 & 58 & 15,2 & 17,0 & 16,0 & 16,5 \\
\hline VI & 97 & 138 & 104 & 83 & 19,8 & 19,0 & 20,0 & 19,7 \\
\hline VII & 63 & 123 & 32 & 61 & 22,0 & 21,0 & 23,0 & 21,4 \\
\hline VIII & 39 & 135 & 123 & 52 & 21,7 & 20,0 & 20,0 & 20,9 \\
\hline IX & 42 & 66 & 23 & 36 & 16,3 & 18,0 & 19,0 & 17,0 \\
\hline Total & 442 & 530 & 419 & 338 & & & & \\
\hline Average & & & & & 17,9 & 17,8 & 18,5 & 17,8 \\
\hline
\end{tabular}

In the three years of the trial (2004-2006), the rainfall sums per vegetation period were significantly above the long-term average. The monthly rainfall was unevenly distributed. The significantly higher rainfall than the long-term average recorded in April 2004 (112 mm) was quite favorable for successful red clover establishment. Maximum rainfall in the second year of the trial was reached in the summer months (June, July and August). It was nearly 2 to 2.5 times higher than 
the long-term average for that period, and it positively affected the quality of forage from the second and third cuts (increased crude proteins content). The rainfall sums recorded in June and August $2006(104 \mathrm{~mm}$ and $123 \mathrm{~mm}$, respectively) were much higher than the long-term average values.

Considering the mean monthly temperatures for the vegetation periods of 2004-2005, it can be noted that there was no major departure from the long-term averages. The minor deviations from the long-term average values recorded in April, July and August 2006 increased the average temperature for the vegetation period by about $1^{\circ} \mathrm{C}$.

\section{Results and Discussion}

Analyzing the content of the studied quality characteristics in three red clover cultivars, statistically significant differences were found between the cuts (Table 3) but there was no significant difference between the cultivars (Table 2). Still, Una, the red clover cultivar developed in Novi Sad, had somewhat increased contents of crude proteins and potassium (K) (Table 2).

Table 2. Variation among red clover cultivars in crude proteins, structural carbohydrates, fats and minerals during 2004-2006

\begin{tabular}{|l|c|c|c|c|c|c|c|c|c|}
\hline \multirow{2}{*}{ Cultivar } & \multirow{2}{*}{$\begin{array}{c}\text { Crude } \\
\text { proteins } \\
\end{array}$} & \multicolumn{2}{|c|}{$\begin{array}{c}\text { Structural } \\
\text { carbohydrates (\%) }\end{array}$} & \multirow{2}{*}{$\begin{array}{c}\text { Crude } \\
\text { fats (\%) }\end{array}$} & \multirow{2}{*}{$\begin{array}{c}\text { Ashes } \\
(\%)\end{array}$} & \multicolumn{4}{|c|}{ Minerals (\%) } \\
\cline { 8 - 11 } & & NDF & ADF & & & Ca & $\mathrm{P}$ & $\mathrm{Na}$ & $\mathrm{K}$ \\
\hline K-17 & 17.59 & 39.41 & 30.61 & 2.04 & 7.89 & 1.90 & 0.29 & 0.10 & 2.29 \\
\hline Kolubara & 17.96 & 38.63 & 29.17 & 1.99 & 8.15 & 1.89 & 0.30 & 0.07 & 2.45 \\
\hline Una & 18.32 & 36.97 & 30.11 & 1.97 & 8.18 & 1.80 & 0.30 & 0.08 & 2.53 \\
\hline Average & 17.95 & 38.34 & 29.96 & 2.00 & 8.07 & 1.86 & 0.30 & 0.08 & 2.42 \\
\hline LSD 0.05 & 0.72 & 3.28 & 1.52 & 0.29 & 0.58 & 0.14 & 0.03 & 0.03 & 0.20 \\
0.01 & 0.99 & 4.55 & 2.11 & 0.41 & 0.81 & 0.20 & 0.05 & 0.05 & 0.28 \\
\hline
\end{tabular}

In the three years of research, variation of crude proteins content in red clover dry matter was significant among the different cuts (Table 3 ). The highest content of crude proteins was found in the second cut in all three years, indicating a seasonal change in quality. The increased protein content in dry matter from the second indicated that this part of growing season had favorable agro-ecological conditions for leaf formation. 
Table 3. Seasonal variation in crude proteins, structural carbohydrates, fats and minerals in red clover cultivars during 2004-2006

\begin{tabular}{|l|c|c|c|c|c|c|c|c|c|}
\hline $\begin{array}{l}\text { Date of } \\
\text { cutting }\end{array}$ & \multirow{2}{*}{$\begin{array}{c}\text { Crude } \\
\text { proteins } \\
\end{array}$} & \multicolumn{2}{|c|}{$\begin{array}{c}\text { Structural } \\
\text { carbohydrates (\%) }\end{array}$} & \multirow{2}{*}{$\begin{array}{c}\text { Crude } \\
\text { fats (\%) }\end{array}$} & \multirow{2}{*}{$\begin{array}{c}\text { Ashes } \\
(\%)\end{array}$} & \multicolumn{4}{|c|}{ Minerals (\%) } \\
\cline { 8 - 11 } & & NDF & ADF & & & Ca & P & Na & K \\
\hline 21.07 .2004 & 15.81 & 35.6 & 30.2 & 2.13 & 8.68 & 1.98 & 0.25 & 0.11 & 2.71 \\
\hline 11.09 .2004 & 17.99 & 33.4 & 22.9 & 2.55 & 8.11 & 2.07 & 0.24 & 0.05 & 2.08 \\
\hline 13.05 .2005 & 16.82 & 35.6 & 29.7 & 2.13 & 8.48 & 1.73 & 0.30 & 0.11 & 2.56 \\
\hline 23.06 .2005 & 19.48 & 42.0 & 30.5 & 1.76 & 8.52 & 2.00 & 0.31 & 0.08 & 2.72 \\
\hline 01.08 .2005 & 18.39 & 38.5 & 32.5 & 2.48 & 7.85 & 1.81 & 0.32 & 0.07 & 2.51 \\
\hline 06.10 .2005 & 19.40 & 45.5 & 33.8 & 1.68 & 8.21 & 1.66 & 0.37 & 0.09 & 2.54 \\
\hline 18.05 .2006 & 17.92 & 37.9 & 28.6 & 1.72 & 7.45 & 1.97 & 0.24 & 0.07 & 1.93 \\
\hline 27.06 .2006 & 18.23 & 38.1 & 31.6 & 1.54 & 7.31 & 1.68 & 0.36 & 0.11 & 2.35 \\
\hline Average & 17.96 & 38.3 & 29.97 & 2.00 & 8.08 & 1.86 & 0.30 & 0.09 & 2.43 \\
\hline LSD 0.01 & 1.17 & 5.36 & 2.49 & 0.48 & 0.95 & 0.23 & 0.06 & 0.06 & 0.33 \\
0.05 & 1.63 & 7.44 & 3.45 & 0.66 & 1.32 & 0.33 & 0.08 & 0.08 & 0.46 \\
\hline
\end{tabular}

Knowledge of changes in quality of red clover forage during growing season is important when preparing meals for ruminants, to ensure a satisfactory relationship between structural and unstructured carbohydrates (Grubić and Adamović, 2003). Considering the contents of neutral and acid detergent fibers highest values were obtained in the second year of growing (Table 3), when red clover had the highest total biomass production (Vasiljević et al., 2010).

Low but, in terms of ruminant feeding, optimum values of NDF and ADF (33.4\% and $22.9 \%$, respectively) were obtained in the fall cut in the year of red clover establishment (Table 3).

Studying the content of individual fractions of structural carbohydrates $\mathrm{NDF}, \mathrm{ADF}$, hemicellulose) in five red clover cultivars grown in the period 20042006, Vasiljević et al. (2008) found statistically significant differences between the cuts (Table 4), while no difference was found between the cultivars (Table 5). The contents of both fractions of cellulose fiber (NDF and ADF) was increased in summer, due to high temperatures and accelerated aging (development) of plants.

Significantly high contents of fats were registered or at the end or in the later part of growing season in the first and second year of growing (Table 2). In contrast to the seasonal variation of fats content in dry matter of red clover, there were no significant differences between the cultivars (Table 1).

Red clover is a rich source of minerals which are essential in the diet of ruminants. The content of minerals is high in early stages of red clover growth, i.e., in the leaves. This in turn indicates the importance of preserving leaves during processing, storage and use of red clover hay. Highest contents of minerals were recorded at the beginning of the growing seasons (first and second cutting) in 2004 and 2005 (Table 3). 
Studying the quality characteristics of dry matter at different stages of development of red clover cultivars, Vasiljevic et al. (2005) found that there was no difference in the content of minerals at the stages of budding and early bloom, while the average ash content in the two stages was $8.9 \%$. A somewhat lower value of this characteristic was found at the stage of full bloom (7.8\%). Dinic et al. $(1990,1994)$ reported the ash content at the stage of early bloom in red clover of $10.3 \%$.

In addition to nitrogen $(\mathrm{N})$, other important biogenous elements in the diet of ruminants are phosphorus $(\mathrm{P})$, potassium $(\mathrm{K})$ and calcium $(\mathrm{Ca})$. The effect of seasonal variations on the contents of these macroelements in red clover dry matter was more important than the effect of genotype. The phosphorus content per cut ranged from 0.23 to $0.37 \%$, the potassium content from 1.93 to $2.72 \%$ (Table 3 ). Highest contents of calcium (Ca), similarly to the crude proteins content, were determined in dry matter from the second cuts in 2004 and 2005.

Fairey (1988) stated that the phosphorus content in red clover dry matter ranges from 0.2 to $0.4 \%$, if the yield is not limited by phosphorus deficiency. Thus, to achieve a dry matter yield of $10,000 \mathrm{~kg} \mathrm{ha}^{-1}$ it is necessary to provide between 20 and $40 \mathrm{~kg} \mathrm{ha}^{-1}$ phosphorus (P) per year. The same author also reported that there is about $1.8 \%$ of $\mathrm{K}$ in red clover dry matter, so, to achieve a dry matter yield of $10,000 \mathrm{~kg} \mathrm{ha}^{-1}$ it is necessary to provide red clovers with $180 \mathrm{~kg} \mathrm{ha}^{-1}$ of potassium (K) per year.

\section{Conclusion}

The three-year research showed that specific seasonal changes occurred in the most important quality characteristics of dry matter (forage) of the three red clover cultivars (K-17, Kolubara, Una) that dominate the commercial production in the Republic of Serbia.

Highest contents of crude proteins and calcium (Ca) in red clover dry matter were determined in the second cuts in 2004 and 2005. These high values indicated that this part of growing season has favorable agroecological conditions for leaf formation.

Significantly high contents of crude proteins (18.32\%) and potassium $(2.53 \%)$ were found in the cultivar Una, which had been developed in Novi Sad.

Highest values of both fractions of cellulose fiber (NDF and ADF) were determined in the second year of growing, when red clover also had the largest total biomass production.

Significantly high contents of fats were recorded at the end or in the later part of growing season in the first and second year of growing $(2.55 \%$ and $2.48 \%$, respectively). 
Highest contents of minerals were found at the beginning of the first and second growing season. It should be noted here that the contents of basic biogenous elements, phosphorus and potassium, were within the expected limits.

\section{Acknowledgment}

Research was financed by the Ministry of Education and Science of Republic of Serbia within projects: TR 20090 and TR 20083.

\section{Sezonske promene sadržaja proteina, strukturnih ugljenih hidrata, masti, mineralnih materija u suvoj materiji crvene deteline (Trifolium pratense $\mathbf{L}$.)}

S. Vasiljević, B. Ćupina, Đ. Krstic, I. Pataki, S. Katanski, B. Milošević

\section{Rezime}

Crvena detelina (Trifolium pratense L.) je druga po značaju višegodišnja krmna leguminoza. Slično lucerki značajan je izvor proteina, neophodnih u ishrani domaćih životinja, a naročito preživara. Cilj rada je bio da se tokom jednog proizvodnog ciklusa crvene deteline, u periodu 2004-2006. godine po otkosima utvrde najvažniji parametri kvaliteta suve materije: sadržaj sirovih proteina, strukturnih ugljenih hidrata, masti i mineralnih materija kod tri domaće sorte crvene deteline: K-17, Kolubara i Una. Najveći sadržaj sirovih proteina u sve tri godine ispitivanja je utvrđen u drugom otkosu. Značajno veći sadržaj sirovih proteina $(18,32 \%)$ i kalijuma (K-2,53 \%) je utvrđen kod NS-sorte crvene deteline Une. Statistički značajno veće vrednosti obe frakcije celuloznih vlakana (NDF, ADF) su utvrđene u drugoj godini života crvene deteline. Najveći sadržaj mineralnih materija je utvrđen početkom vegetacije prve $(8,68 \%)$ i druge godine proizvodnog ciklusa $(8,52 \%)$ crvene deteline, pri čemu treba istaći da se sadržaj osnovnih biogenih elementa: fosfora i kalijuma nalazio u očekivanim optimalnim granicama.

\section{References}

BELONGER G., TREMBLAY G.F. (2010): Fodder quality of legume-based pastures. NJF Seminar 432 The potential of forage legumes to sustain a high agricultural productivity - A Nordic perspective. NJF Report, 6, 3, 97-112. Hvanneyri, Iceland - 20-22 June 2010. 
BUXTON D.R., HORNSTEIN J.S., WEDIN W.F., MARTEN G.C. (1985): Forage quality in stratified canopies of lucerne, birdsfoot trefoil and red clover. Crop Sci, 25, 273-279.

BUXTON D.R., HORNSTEIN J.S. (1986): Cell wall concentration and components in stratified canopies of alfalfa, birdsfoot trefoil and red clover. Crop Sci, 26, 180-184.

DINIĆ B. (1990): Uticaj provenjavanja silo mase crvene deteline i konzervansa na kvalitet silaže. Arhiv za poljoprivredne nauke, 51, 183, 235-244.

DINIĆ B., LUGIĆ Z., STOŠIĆ M., RADOVIĆ J. (1994): Uticaj provenjavanja i nivoa kukuruzne prekrupe na kvalitet silaže crvene i bele deteline. Biotehnologija u stočarstvu, 10, 3-4, 71-80.

FAIREY D.T. (1988): Red clover Agriculture, Canada, Publication 1614/E, Research Station, Beaverlodge, Alberta.

GRUBIĆ G., ADAMOVIĆ M. (2003): Ishrana visokoproizvodnih krava, Premis, Beograd, Srbija, 33-40.

IGNJATOVIC S., VUCETIC J., LUGIC Z., DINIC B. (2001): Effect of Growth Stage on Macro and Trace Elements Content in Red and White Clover. Journal of Scientific Agricultural Research, 62, 220, 309-316.

MARKOVIĆ J., IGNJATOVIĆ S., RADOVIĆ J., LUGIĆ Z. (2007): Uticaj faze razvića na sadržaj makro i mikroelemenata u lucerki i crvenoj detelini. Zbornik radova, Institut za ratarstvo i povrtarstvo, Novi Sad, 44, 1, 401-406.

TAYLOR N.L., QUESENBERRY K.H. (1996): Red Clover Science. Current Plant Sciences and Biotechnology in Agriculture, 28, 65-67.

VASILJEVIC S., KATIC S., MIHAILOVIC V., CUPINA B., MILIC D., MIKIC A., KARAGIC DJ., PATAKI I. (2005): Effect of cutting date on quality of red clover forage. Offered Papers of the XX International Grassland Congress Grasslands - a Global Resource, Dublin, Ireland, 26 June - 1 July 2005, 269.

VASILJEVIC S., GLAMOCIC D., JAJIC I., CUPINA B., KATIC S., MILIC D., MIKIC V. (2008): Fibre fractions of red clover (Trifolium pratense L) at different harvests over two seasons. EGF, Grassland science in Europe, 13, 510-513.

VASILJEVIĆ S., MILIĆ D., MIKIĆ A. (2009): Chemical attributes and quality improvement of forage legumes. Biotechnology in Animal Husbandry, 25, 5-6, Book I, 493-504.

VASILJEVIĆ S, MIHAILOVIĆ V, KATIĆ S, MIKIĆ A, KARAGIĆ Đ (2010): Potencijal rodnosti sorti crvene deteline (Trifolium pratense L.). Ratarstvo i povrtarstvo, Novi Sad, 47, 1, 217-223.

WIERSMA D. W., SMITH R. R., MLYNAREK M. J. (1998): Harvest management effects on red clover forage yield, quality and persistence, J. Prod. Agric., 11, 3, 309-313. 